\title{
Air Quality Monitoring and Forecasting
}

\author{
Pius Lee ${ }^{1,2, *}$, Rick Saylor ${ }^{1}$ and Jeff McQueen ${ }^{3}$ \\ 1 NOAA/Air Resources Laboratory, NOAA Center for Weather and Climate Prediction, \\ College Park, MD 20740, USA; rick.saylor@noaa.gov \\ 2 Center for Spatial Information Science and Systems, George Mason University, Fairfax, VA 22030, USA \\ 3 NOAA/NCEP/Environmental Modeling Center, NOAA Center for Weather and Climate Prediction, \\ College Park, MD 20740, USA; jeff.mcqueen@noaa.gov \\ * Correspondence: pius.lee@noaa.gov
}

Received: 27 February 2018; Accepted: 28 February 2018; Published: 1 March 2018

Air quality forecasting is a vital tool for local health and air managers to make informed decisions on mitigation measures to reduce public exposure risk. Given a forecast of impending poor air quality, air quality managers may issue car-pooling advisories, authorize free public transportation or impose other mitigation and warning measures. Air composition monitoring and exposure records can inform long-term trends of major air pollutants and their health impacts. Epidemiologists use long term composition data to understand air pollution related diseases and mortality rates to support public health policies. This Special Issue highlights the interplay and co-benefit of air quality monitoring and forecasting.

Public health is under a constant threat by air pollution across the world in various degrees and manifestations. In China, rapid economic growth has resulted in increased occurrences of poor air quality. In this special issue, Lu et al. [1] of Wuhan University and Zhou et al. [2] of Chengdu University respectively studied urban haze and the distribution of multiple pollutants in China. Lyu et al. [3] of Tsinghua University and Georgia Institute of technology advanced particulate matter forecasts in China. Zhao et al. [4] of Nanjing University studied the strong response of emission controls during a recent Youth Olympics event in Nanjing, China.

Ground truth of air constituent concentrations is determined by measurements. Woodall et al. [5] of the US EPA conducted an intriguing study about hand held air composition measurement devices. Constantin et al. [6] of the University of Galati, Romania, used an ultralight trike and flux calculations to measure nitrogen dioxide vertical column density. Bray et al. [7] of North Carolina State University characterized pollutants emitted from coal-fired power plants in Eastern USA. Baker and Pan [8] of NOAA's Air Resources Laboratory, developed a software tool which utilized many in-situ and surface monitoring network measurements to evaluate forecast model performance. Lightstone et al. [9] of City College of New York explored neural networks as a means for air quality forecasts. Environmental and Climate Change Canada's Munoz-Alpizar et al. [10] studied the impact wildfire pollution on public health, and Ménard and Deshaies-Jacques [11,12] analyzed chemical data evaluations by cross-validation statistical analysis.

It is clear that air pollution remains a global problem and that air quality monitoring, forecasting and mitigation begins as a local effort conducted in concert with global partners. The articles selected in this Special Issue speak volumes to this fact many times over across the globe. We thank the editing office for their excellent support to realize this herculean achievement to collect and publish the cutting edge articles in this issue.

Conflicts of Interest: The authors declare no conflict of interest. 


\section{References}

1. Lu, W.; Ai, T.; Zhang, X.; He, Y. An Interactive Web Mapping Visualization of Urban Air Quality Monitoring Data of China. Atmosphere 2017, 8, 148. [CrossRef]

2. Zhou, T.; Sun, J.; Yu, H. Temporal and Spatial Patterns of China's Main Air Pollutants: Years 2014 and 2015. Atmosphere 2017, 8, 137. [CrossRef]

3. Lyu, B.; Zhang, Y.; Hu, Y. Improving $\mathrm{PM}_{2.5}$ Air Quality Model Forecasts in China Using a Bias-Correction Framework. Atmosphere 2017, 8, 147. [CrossRef]

4. Zhao, H.; Zheng, Y.; Li, T. Air Quality and Control Measures Evaluation during the 2014 Youth Olympic Games in Nanjing and its Surrounding Cities. Atmosphere 2017, 8, 100. [CrossRef]

5. Woodall, G.M.; Hoover, M.D.; Williams, R.; Benedict, K.; Harper, M.; Soo, J.-C.; Jarabek, A.M.; Stewart, M.J.; Brown, J.S.; Hulla, J.E.; et al. Interpreting Mobile and Handheld Air Sensor Readings in Relation to Air Quality Standards and Health Effect Reference Values: Tackling the Challenges. Atmosphere 2017, 8, 182. [CrossRef] [PubMed]

6. Constantin, D.-E.; Merlaud, A.; Voiculescu, M.; Dragomir, C.; Georgescu, L.; Hendrick, F.; Pinardi, G.; Van Roozendael, M. Mobile DOAS Observations of Tropospheric $\mathrm{NO}_{2}$ Using an UltraLight Trike and Flux Calculation. Atmosphere 2017, 8, 78. [CrossRef]

7. Bray, C.D.; Battye, W.; Uttamang, P.; Pillai, P.; Aneja, V.P. Characterization of Particulate Matter (PM 2.5 and $\mathrm{PM}_{10}$ ) Relating to a Coal Power Plant in the Boroughs of Springdale and Cheswick, PA. Atmosphere 2017, 8, 186. [CrossRef]

8. Baker, B.; Pan, L. Overview of the Model and Observation Evaluation Toolkit (MONET) Version 1.0 for Evaluating Atmospheric Transport Models. Atmosphere 2017, 8, 210. [CrossRef]

9. Lightstone, S.D.; Moshary, F.; Gross, B. Comparing CMAQ Forecasts with a Neural Network Forecast Model for $\mathrm{PM}_{2.5}$ in New York. Atmosphere 2017, 8, 161. [CrossRef]

10. Munoz-Alpizar, R.; Pavlovic, R.; Moran, M.D.; Chen, J.; Gravel, S.; Henderson, S.B.; Ménard, S.; Racine, J.; Duhamel, A.; Gilbert, S.; et al. Multi-Year (2013-2016) PM 2.5 Wildfire Pollution Exposure over North America as Determined from Operational Air Quality Forecasts. Atmosphere 2017, 8, 179. [CrossRef]

11. Ménard, R.; Deshaies-Jacques, M. Evaluation of analysis by cross-validation. Part I: Using verification metrices. Atmosphere 2017, 8, 86 .

12. Ménard, R.; Deshaies-Jacques, M. Evaluation of analysis by cross-validation. Part II: Diagnostics and optimization of analysis error covariance. Atmosphere 2017, 8, 70. 